\title{
䫤面神経麻庫におけろ星状神経節ブロックおよび針治嫁の併用について
}

\author{
伊介昭弘・小泉秀行・田辺明康 \\ 永野攸*・虚英和*大大高道夫"
}

\section{A therapy of facial paralysis by stellate ganglion block and electric acupuncture}

\author{
Akihiro IkaI - Hideyuki KoIzumI - Haruyasu TANABE \\ Osamu Nagano* • Ying-he Lino* - Michio OhtakA*
}

\begin{abstract}
Various treatment methods are now used for facial paralysis, however, no established method is yet available. In the present study, a combination therapy of stellate ganglion block and electric acupuncture was performed in 42 cases of facial paralysis with favorable results obtained as follows:

The combination therapy was effective on not only fresh cases but also old cases. In addition, it was also useful for treating diabetes mellitus and hypertension.

Some fresh cases of Bell's paralysis were, on the other hand, resistant to this therapy probably due to virus infection. In fact, an increased virus antibody titer in serum was occasionally observed in some of these intractable cases.

Thus, in the case of facial paralysis, stellate ganglion block and eloctric acupuncture are recommended to perform after the onset of disease as soon as possible in addition to the determination of virus antibody titer.
\end{abstract}

Key words: facial paralysis, stellate ganglion block, electric acupuncture

\section{緒言}

顔面神経麻㾇の治療法には従来より種々なものがある が，十分に確立されていないのが現状であり，各施設に よってもその治療方法が異なっている.一般に顔面神経 麻疸のらち. Bell 麻癗は予後が比較的よく，50\%が自然 治窟するといわれており，薬物炕よっても60〜80\%が完 治するといわれる1．しかしながら不快症状をのこすこ

東京怒恵会医科大学歯科学教室 （主任：田辺晴康教授）

* 東京萑恵会医科大学麻醉科学教室 （主任：小林建一教授）

Department of Dentistry, The Jikei University School of Medicine (Chief: Prof. Haruyasu Tanabe)

* Department of Anesthesiology, The Jikei University School of Medicine (Chief: Prof. Kenichi Kobayashi)

受付日：昭和59年 3 月 23 日
とがあり，また棵旧例に対してははとんど圽果がないと いわれている.

今回，わたくしたちは顔面神経麻疩に対して星状神経 節プロック（以下 SGB と略す）と通電針治㞠（以下 EAP と略す）を併用し良好な結果が得られたので報告 する.

\section{対象および治㾦方法}

症例は昭和54年 1 月か 558 年 6 月までに東京慈恵会医 科大学附属病院麻醉科に来院した碩面神経麻軯の患者の らち、SGB と EAP を併用した 42 名について 分析し た.

治療方法は, 原則として週 3 回 SGB とEAPを同日 に行った．SGB は前方傍気管法により $1 \%$ ×ピバカイ ン $5 \sim 8 \mathrm{ml}$ を用い,フフロック針は $23 \mathrm{G}, 32 \mathrm{~mm}$ のるの を使用した。

EAP は，患㑡の顔面に 6 ～8 か所と両側の 合谷を取 穴し15分間通電した. 顔面の取穴部位としては，太陽， 陽白，攅竹，迎香，下関，頖車，地倉などとした（図 
衰 1 May の点数衰

\begin{tabular}{|c|c|c|c|c|c|c|c|c|c|}
\hline & $\begin{array}{c}\text { 年 } \\
\text { DR. }\end{array}$ & 常 & 日 & $\begin{array}{c}\text { 年 } \\
\text { DR. }\end{array}$ & 月 & 日 & $\begin{array}{c}\text { 年 } \\
\text { DR. }\end{array}$ & 月 & 日 \\
\hline 1. 全体の零張 & 10 & 5 & 0 & 10 & $\mathbf{5}$ & 0 & 10 & 5 & 0 \\
\hline 2. 前額作等 & 10 & 5 & 0 & 10 & 5 & 0 & 10 & 5 & 0 \\
\hline 3. 完全的眼 & 10 & 5 & 0 & 10 & 5 & 0 & 10 & 5 & 0 \\
\hline 4. 眐 目 & & 5 & $\begin{array}{c}\mathrm{mm}) \\
0\end{array}$ & & 5 & $\underset{0}{\mathrm{~mm})}$ & 10 & 5 & $\underset{0}{\mathrm{~mm})}$ \\
\hline 5. 留 & 10 & 5 & 0 & 10 & 5 & 0 & 10 & 5 & 0 \\
\hline 6. 画牙の出出 & 10 & 5 & 0 & 10 & 5 & 0 & 10 & 5 & 0 \\
\hline 7. 口笛遇的 & 10 & 5 & 0 & 10 & 5 & 0 & 10 & 5 & 0 \\
\hline 8. 䫅ふくらませ運功 & 10 & 5 & 0 & 10 & 5 & 0 & 10 & 5 & 0 \\
\hline 9. 下厚の下制 & 10 & 5 & 0 & 10 & 5 & 0 & 10 & 5 & 0 \\
\hline 10. 垔部の孯張 & 10 & 5 & 0 & 10 & 5 & 0 & 10 & 5 & 0 \\
\hline 合 㖕 点 数 & & & & & & & & & \\
\hline
\end{tabular}

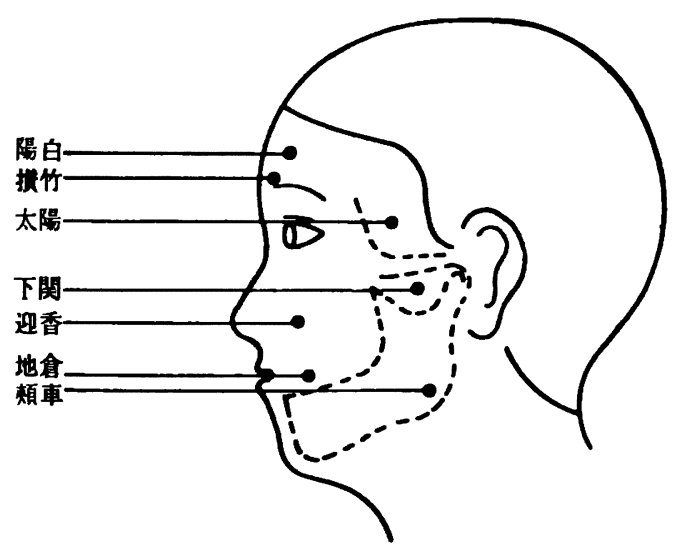

図 1 取穴部位

1).

治寮効果の判定には，May のスコアー2)を用い初診 時および治療10回施行ごとに評価した. May のスコフ 一は，顔面の表情筋を10項目について钼察し，健側と比 㢺して normal を10点, weak 5 点, absent 0 点と したものであり全体として正常であれば 100 点とする. また May のスュアーの補足として随伴症状についての 問診を行った（表 1，2）.

この May のスコアーは, 麻㾝の程度を数量的に把握 でき，躡床的な機能面と比較的一致しているので実用的 と思われる. May のスュアーで 80 点以上は, 表情をつ

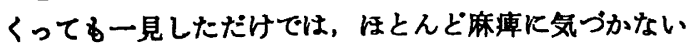
程度であるので「完治」とし，60点以上では，鬼眼や口 趽内に食物がたまる，口角より水がもれるなどの不快な
衰 2 随伴症状
1. 耳後部痛
2. 流䐖
3. 謖覚異常
4. 味筧異常（低下）
5. 洗顔時, 目に水が入る
6. 患㑡口貯内に食物がたまる
7. 口角上り、水,タハュの煙がすれる
8. 会話が不便（特にパビプペポ）

症状は，ほぼ改着されるので「略治」とした。なお，投 薬は行わなかった。

结果

総数42名の5ち男性は25名，女性は17名であり，年㱓 分布は男性では40～50歳代に，女性は20～30瓷に多くみ られた (表 3).

羅患部位の左右差は，ほとんどみられなかったが，男 女別では男性では右傊に多く，女性では逆に左僓に多く みられた（表 4 ）.

麻疸の内訳は, Bell 麻㾝が最も多く31名74\%を占めて いた，その他は，Hunt 症候群の 8 名19\%，術後麻瘪の 3 名 $7 \%$ であった（表 5 ）.

発症より来院までの期間は， 2 週間以上 1 か月末满に 来院したものが13名と最も多く，1 か月末満に来院した あのを合わせると全体の $3 / 4$ を占めていた（表 6 ）.

次に発症より来院までの期間と麻瘏の程度についてみ てみると、1 か月末満に受診したものは, May のスコ 
交 3 䐓女别年䇶分布

\begin{tabular}{c|cc|c}
\hline 年 & 男 & 女 & 旪 \\
\hline$\sim 10$ & 0 & 0 & 0 \\
$\sim 20$ & 0 & 3 & 3 \\
$\sim 30$ & 5 & 4 & 7 \\
$\sim 40$ & 3 & 2 & 5 \\
$\sim 50$ & 7 & 1 & 8 \\
$\sim 60$ & 6 & 3 & 9 \\
$\sim 70$ & 3 & 3 & 6 \\
$\sim 80$ & 1 & 1 & 2 \\
\hline 計 & 25 & 17 & 42 \\
\hline
\end{tabular}

泰 4 西患側别

\begin{tabular}{c|c|c|c}
\hline & 左 & 右 & 两 側 \\
\hline 男 & 7 & 17 & 1 \\
女 & 12 & 5 & 0 \\
\hline 計 & 19 & 22 & 1 \\
\hline
\end{tabular}

表 5 麻痊の内訳

\begin{tabular}{c|c|c|cc}
\hline & Bell 麻㾝 & Hunt 症候群 & 術 & 後 \\
\hline 男 & 20 & 4 & 1 \\
女 & 11 & 4 & 2 \\
\hline 計 & 31 & 8 & 3 \\
\hline
\end{tabular}

表 6 発症より来院までの期間

\begin{tabular}{c|rr|r}
\hline & 男 & 女 & 計 \\
\hline$\sim 1$ 週間 & 4 & 4 & 8 \\
$\sim 2$ 週間 & 7 & 3 & 10 \\
$\sim 1$ か月 & 5 & 8 & 13 \\
$\sim 3$ か月 & 6 & 2 & 8 \\
3 か月〜 & 3 & 0 & 3 \\
\hline
\end{tabular}

アーで20～70点と幅が広く，軽症から重症までみられた か，1 か月以上のものでは20〜30点が多くなり，麻疸の 程度も重㱏であった（表 7 ）.

来院までの期間と治療成績との関係について調べる と， 1 週間未満に来院したものの完治率は 8 名中 6 名75 $\%$ ，同じく 2 週間未満に 来院したものは 10 名中 4 名 40 $\% ， 2$ 週間以上 1 か月未満のbのは13名中 11 名 $84.6 \%$ て あり、1 か月未満に受診したものを合わせると完治率は 68\%であった. しかしながら，1 か月以上 3 か月末満に 来院したものは $22.2 \% ， 3$ か以上のものは完治例はな
永 7 来院までの期间と麻痊の程度

\begin{tabular}{|c|c|c|c|c|c|}
\hline${ } \quad x=$ & $0 \sim$ & $20 \sim$ & $40 \sim$ & $60 \sim$ & $80 \sim$ \\
\hline$\sim 1$ 週間 & & 4 & 1 & 3 & \\
\hline$\sim 2$ 相间 & 1 & 5 & 3 & 1 & \\
\hline$\sim 1$ か月 & & 3 & 6 & 4 & \\
\hline$\sim 3$ か月 & & 6 & 2 & 1 & \\
\hline 3 か月〜 & 2 & & & 1 & \\
\hline It & 3 & 18 & 12 & 10 & 0 \\
\hline
\end{tabular}

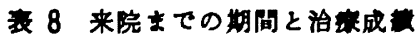

\begin{tabular}{|c|c|c|c|c|c|c|}
\hline \multicolumn{2}{|c|}{$x=7-1$} & \multicolumn{3}{|c|}{ 嚾治 } & \multirow{2}{*}{$\frac{\text { 略治 }}{60 \text { }}$} & \multirow{2}{*}{$\frac{\text { 完治 }}{80 \sim ~}$} \\
\hline 期 & 間 & $0 \sim$ & $20 \sim$ & 40 & & \\
\hline & $\sim 1$ 週間 & & & 1 & 1 & 6 \\
\hline & ～ 2 莀間 & & 1 & 2 & 3 & 4 \\
\hline & $\sim 1$ か月 & & & 2 & & 11 \\
\hline & $\sim 3$ か月 & & & 4 & 3 & 2 \\
\hline & か月〜 & & 1 & 1 & 1 & \\
\hline & 計 & 0 & 2 & 10 & 8 & 23 \\
\hline
\end{tabular}

表 9 初診時およひ治鞁後の May のスコフー

\begin{tabular}{|c|c|c|c|c|c|}
\hline \multirow{2}{*}{ 初診時 } & \multicolumn{3}{|c|}{ 難治 } & \multirow{2}{*}{$\frac{\text { 略治 }}{60 \sim ~}$} & \multirow{2}{*}{$\frac{\text { 完治 }}{80 \sim ~}$} \\
\hline & $0 \sim$ & $20 \sim$ & $40 \sim$ & & \\
\hline $0 \sim$ & & 2 & 1 & & \\
\hline $20 \sim$ & & & 9 & 5 & 4 \\
\hline $40 \sim$ & & & & 2 & 10 \\
\hline $60 \sim$ & & & & 1 & 9 \\
\hline $80 \sim$ & & & & & \\
\hline 計 & 0 & 2 & 10 & 8 & 23 \\
\hline
\end{tabular}

かった（表 8 ).

初診時の麻疸の程度と治寮成賴をみてみると, 初診時 スコアーが20〜30点のものは完治率22.2\%, 同じく40〜 50 点のものは $83.3 \%, 60$ 点以上のるのは $90 \%$ むむった (泰 9 ).

また完治群, 略治群, 難治群の SGB と EAP の回数 は，それぞれ12.8回，14.4回，16.5回であった。

初診時における随伴症状については, 症状の全くみら れなかったるのは 7 名であり，その他は何らかの症状が 認められた. 随伴症状の数と治㙩前後のスコアーを比較 してみると， 0 〜 種類までは数が増えるにつれ治療後 のスコアーも低くなっているが，6種類以上になるとス コアーが60点台であり，大きな差はなかった（表 10）. 
表 10 随伴症状の数と May のスコフーの交化

\begin{tabular}{c|c|c|c}
\hline 症状の数 & 刨 & 治 & 治放 \\
\hline 0 & 7 & 55.0 & 90.0 \\
1 & 3 & 48.3 & 85.0 \\
2 & 6 & 55.8 & 85.0 \\
3 & 5 & 36.0 & 74.0 \\
4 & 8 & 28.1 & 55.0 \\
5 & 6 & 31.7 & 63.3 \\
6 & 4 & 32.5 & 68.8 \\
7 & 3 & 33.0 & 66.6 \\
8 & 0 & - & - \\
\hline
\end{tabular}

表 11 随伴症状の醞類と May のスコフーの变化

\begin{tabular}{|c|c|c|c|}
\hline 随伴症状の理類 & 例数 & 治蝴前 & 治撩後 \\
\hline 1. 耳媵部痛 & 11 & 41.2 & 63.2 \\
\hline 2. 流涋 & 16 & 34.7 & 69.7 \\
\hline 3. 咕覚異常 & 12 & 37.5 & 72.5 \\
\hline 4. 味覚異常（低下） & 11 & 30.5 & 64.5 \\
\hline 5. 洗㕹時, 目に水が入る & 26 & 33.5 & 66.2 \\
\hline 6. 患㑡口空内人食物がたま & 29 & 34.0 & 65.2 \\
\hline $\begin{array}{l}\text { 7. 口角上り水，夕バの煙 } \\
\text { がすれる }\end{array}$ & 19 & 36.6 & 69.7 \\
\hline $\begin{array}{l}\text { 8. 会話が不便（特にパビブ } \\
\text { ¿ボ） }\end{array}$ & 13 & 31.5 & 59.2 \\
\hline
\end{tabular}

随伴症状のらち多いるのは, No. 5 と6であり半数以 上の人に喼められた（表 11）.

また随伴症状の種類により治㞠前後のスコアーを比較 してみたが, 有意の差はなかった $(P<0.01)$.

$$
\text { 考察 }
$$

顔面神経麻㾇の原因は多くのものがあるか，特発性麻

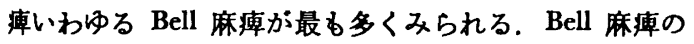
原因としては種々の説があるが，Kettel ${ }^{3)} の 「$ ischemia hypotesis」が一般的である.すなわち顔面神経管内の神 跬䩪が何らかの原因によって浮腫を起こし, 循環不全と

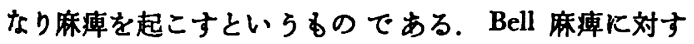
る SGB の有効性については, Swan')が応用して以来 多くの報告がある. Korkis's) は，7 日以内に SGB を開 始した例では92\%が治堍したと報告しているが，わたく したちの症例では 1 週間未満に治療を開始した新鮮例で は, 75\%が完治であった. 発症後, 2 週間以内に施行さ れる SGB は，他の血管拡張剤などよりもすみやかに確 実に顔面神経の循環を促し, 浮腫を除去するのに役立つ ので，自然治瘾よりる早い機能回復が期待できると思わ

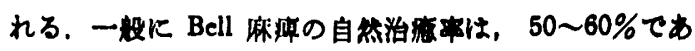
りこの点でるSGB と EAP の侀用は自然治空率を上 回る結果となっている.

さらに SGB と EAP の併用による效果としては，棵

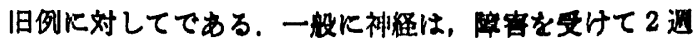

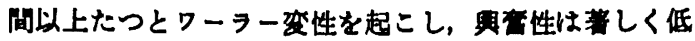
下するといわれる．そこで発症後 2 週闪以上のるのを棵 旧例とナると，わたくしたちの陳旧例では完治率が52\% であり，特に 2 週阙以上 1 か月末满のものでは完治率 84.6\%であった。石河らの)は，陳旧例 46 例に対し SGB と EAP との侀用の結果，11例が著好，13例が有奻であ ったと報告している，以上のよ5K，陳旧例に対してる 回復の可能性があるので，SGB と EAP を陚みる意䅈 があると思われる。

発症年柃，性别については，わたくしたちの症例で は，男性に多く，また年踰分布る男性では比較的高年龄 に，女性ではやや低年跉にみられた，男女差は，諸家の 報告をみると有意の差はないよらであり，発症年掵はあ

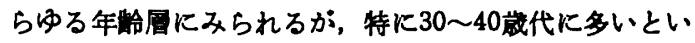
われる。

䍜患部位の左右差では，男性では右側飞多く女性では 左側に多くみられたが，菜和田》が諸家の報告をまとめ たところによると，䍜患側に有意の差はないと述べてい る.

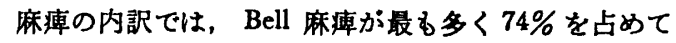
いたが, 顔面神経麻痷の5ち Bell 麻疩の占める割合は, Park, Watkins ${ }^{8}$ か $87 \%$ ，若杉早が88\%と報告しており， 一般に70〜80\%と考劣られており，わたくしたちの症例 です同程度の割合であった。

次に顔面神経の障害部位であるが，わたくしたちが行 った問診より推定するとフブミ骨筋神経での障害は42例 中12例 $28 \%$ であり，それよりむ末梢の鼓索神経での障害 は42例中11例 $26 \%$ と大な差はなかった。一般に障害部 位としては，垂直部および茎乳突孔部に多いとされてい ろか，Jespen ${ }^{10)}$ は Bell 麻瘏 149 例中, アブミ骨筋神経 より上位での障害は $33.6 \%$ であり，大部分がフブミ骨筋 神経より末梢であると報告している。 また細見ら ${ }^{(1)}$ は， フブミ骨筋神経より上位での障害が $67.5 \%$ を占め新鮮例 で多いと述べている．このように種々な報告があるが， これは桧査法の違いにす関係し，わたくしたちは問診で 評価しているので差がでたと思われる.さらに障害部位 を詳細に調べるには，滕神経節機能やフブミ骨筋神経機 能, 鼓索神経機能など耳算科的検查が必要であると考兄 る.

SGB と EAP 以外の他の 治療法を検討してみると， 顔面神経麻疸の外科的療法については手術時期か;問題と され，発症後 7 日〜 2 か月とさまざまな意見がある ${ }^{12)}$. また反対意見もあり，Adour ${ }^{13)}$ は非手術群，早期手術 群, 陳旧例手術群を比較検討して差がないと報告してい 


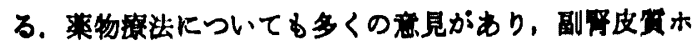
ルモンの 1 日量も $80 \mathrm{mg}, 30 \sim 50 \mathrm{mg}, 15 \mathrm{mg}$ など投年 目网しても一定しておらナ゙，さらに他の疾忽たとえば 高血压，糖病病などで使用できないこともある．以上の ことからす SGB と EAP とよる治举法は有利でり， 大いK眯洒されるるのであると思われる。

このよらK SGB と EAP の併用による治洯法はい

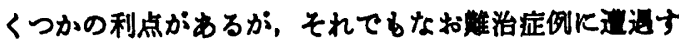
ることがある。一期にウイルスによる Hunt 症候群は，

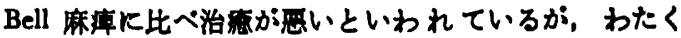
したちの症例の中には新鲜例の Bell 麻㾍飞おいてす難 治のるのが琶められた。この原因としては，吉田 ${ }^{(4)}$ ，若

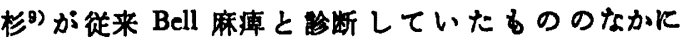
は，ウイルスによる感染により神経麻㾝をきす例が照 められると報告している，とりわけ疮疮ウイルスが更要 視されている．若杉》は Bell 麻㾝の患者のウイルス抗 体価を 测定したところ 143 例中，疮疮ウイルス $20.3 \%$ ， 単純疮颜ウイルス72\%，ムンブスウイルスは $18.9 \%$ 晹性 であったと述へている．実際わたくしたちの雉治症例の 中Кはウイルスの抗体価の高いるのを認めている.一籼 に疮疹ウイルスは，ほとんどの人性抗体価が 8 倍以下で あるので明らかに保有率が高いといえる。 また単純疮疹 ウイルスは，8倍以上の抗体価をすっている人は 6 割は どいるので有意仅保有率が高いとはいえない．臨床面か らは，流感や体調がおるわしくないとき発症することが 多く、このことからあウイルスの感染が示唆される. 富 田 ${ }^{14)}$ 生，強い疼痡，感冒，発熱の先行，炎症性血液所 見, 高度の味覚障害などの莚状を有するるのは，ウイ ルスによる感染が多いと述へてている．以上のことから Bell 麻瘏と診断されたなかには，ウイルスの感染によ るるのが多いと考えられる．したがって初診時より血清 学的にウイルスの抗体価を測定する必要があり，またウ イルス感染の有無によっても治噔方法も異なってくる. すなわちウイルス感染による Bell 麻瘻や Hunt 症候群 では， ケーグロブリン，抗炎症郕，抗ウイルス郕を主体と した治㫫をすべきであり，副盈皮質ホルモンの投与は， 脳焱などの沉発化を助長することもあるので慎重にすべ きである ${ }^{14)}$ ，ウイルス感染炕よる麻瘒にせよ，特発性の 麻瘏にせよ，いずれにしてす顔面神経に乏血性変化をき たしていることから，わたくしたちは SGBを行い，血 流の改善を図っている.さらに EAP により表情筇のト レーニンクと局所の血流改善を期待して行っている.こ のようКウイルスによる感染の有無に関係なく行えるの ๖，大きな利点といえる。

\section{結語}

顔面神経麻㾇の患者 42 名について SGB と EAP を併 用し,以下のよらな結果が得られた。
1. 性别で具性25名，女性17名であり，年腧分布は

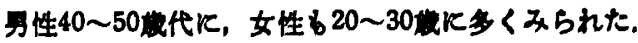

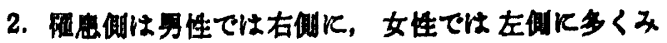
られた。

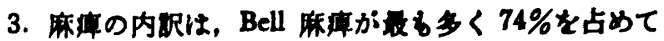

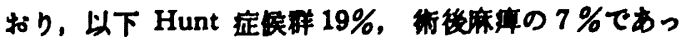
た.

4. 発症より来院までの期间は，2道问以上 1 か月未

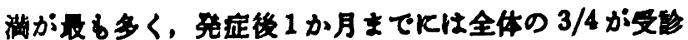
していた.

5. 発症より来院までの期間が 1 か月末消の者の 麻草 の程度は，怪庭から自定まで征々みられたが，1か月以 上のものでは直㱏例がほとんどであった。

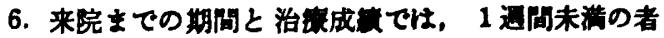
の完治率は75\%，同しくく 1 週间以上 2 週间未渵では40\%， 2 週間以上 1 か月末满で壮 $84.6 \%$ ，1 か月以上 3 か月末 渵では22.2\%であった。

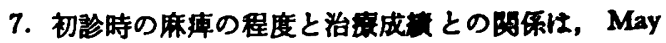
のスコフーが20〜30点では完治率は22.2\%，40〜50点で は83.3\%，60点以上では90\%であった。

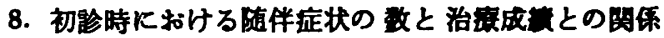

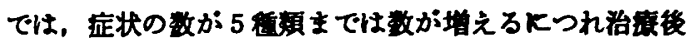

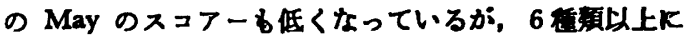
なるとはとんど差はなかった。

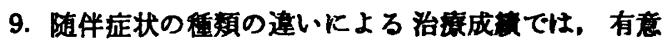
の差はなかった。

本諭文の要旨は，第28回日本口躁外科学会全（昭和 58年 9 月)，お上ひ第 11 回日本畨科麻醉学会全会(昭和 58年10月)において発表した。

\section{引用文 献}

1）小田代攻美：颜面神泽麻㾝火对する星状神跬節 ブロックの协果. 麻醉 19: 890-896 1970.

2) May, M.: Facial paralysis, peripheral type: A proposed method of reporting. Laryngoscope 130: 33-37 1970.

3) Kettel, K.: Bell's palsy-pathology and surgery. Arch Otolaryng 46: 427-430 1947.

4) Swan, D.M.: Stellate block in Bell's palsy. JAMA 150: 32-42 1952.

5) Korkis, F.B.: The early manegement of Bell's palsy by cervical sympathetic block. J Laryngo Otol 77: 50-58 1963.

6) 石河消彦，木村邦夫，他：顔面神跬麻㡷 (Bell 麻症）反対する星状神経節ブロックおよび猃併 用療法について。䣽床麻醉 2: 404-408 1978.

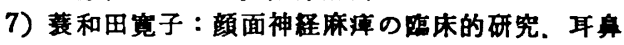
區床 62: 735-798 1969.

8) Park, H.W. and Watkins, A.L.: Facial para- 
lysis-Analysis of 500 cases. Arch Phys Med 30: 749-762 1949.

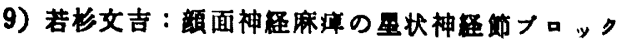
法法，日本医事新郝 2576：25-31 1973.

10) Jespen, O.: Topognosis of Facial Nerve Lesion. Arch Otolaryng 81: 446-458 1965.

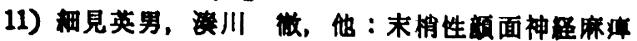
（特に Bell 麻库）の妵宫部位について。年 監床 66: 299-305 1973.

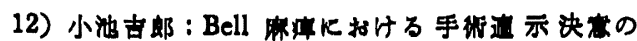

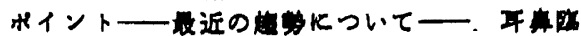
林 72: 705-709 1979.

13) Adour, K.K.: Prednisone treatment for idiopathic facial paralysis (Bell's palsy). N Engl J Med 287: 1247-1268 1972.

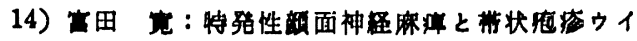
ルス—ルーチン・テストの提唱——日本医 本新蛝 2459: 31-34 1971. 